\title{
A GUERRA DE PORECATU: PÉS VERMELHOS DE SANGUE EM BUSCA DE UM ELDORADO
}

\section{ARTIGO ORIGINAL}

ZAMBOLIN, Rosimeire Aparecida Asunção ${ }^{1}$

PRIORI, Angelo ${ }^{2}$

ZAMBOLIN, Rosimeire Aparecida Asunção. PRIORI, Angelo. A Guerra de Porecatu: Pés vermelhos de sangue em busca de um Eldorado. Revista Científica Multidisciplinar Núcleo do Conhecimento. Ano 05, Ed. 10, Vol. 03, pp. 96-115. Outubro de 2020. ISSN: 2448-0959, Link de acesso: https://www.nucleodoconhecimento.com.br/historia/guerra-de-porecatu

\section{RESUMO}

Este estudo de revisão bibliográfica, teve como objetivo a apresentação da Guerra de Porecatu, que ocorreu em meados dos anos 40 e início dos anos 50, e que é considerada de grande importância para História do Paraná e do Brasil, haja vista sua amplitude conceitual passar pela abordagem do conceito de História Regional e ser revelado pela História Nacional na medida em que discorre a respeito do problema da luta pela terra, neste casos envolvendo alguns grupos em especial: os posseiros, os

${ }^{1}$ Especialista em Educação Inclusiva (UCB); Especialista em Ciência da Religião pelo Centro Universitário Campos de Andrade- UNIANDRADE, de Curitiba; Especialista em História das Revoluções e dos Movimentos Sociais, pela Universidade Estadual de Maringá (UEM, 2017); Graduada em Pedagogia, pela Universidade Castelo Branco (UCB) do Rio de Janeiro; graduada em Geografia, pelo Centro Universitário FiladélfiaUNIFIL- Londrina; Graduada em História, pela Universidade Estadual de Maringá (UEM) de Maringá.

${ }^{2}$ Orientador. Doutorado em História e Sociedade. Mestrado em História e Sociedade. Mestrado em História e Sociedade. 
grileiros e os fazendeiros. O trabalho também pode ser visto como estratégia pedagógica, ou seja, uma forma de abordar a construção do conhecimento histórico, e por se tratar de um levantamento teórico de cunho qualitativo, apropriou-se dos resultados dos estudos de renomados autores como o historiador Angelo Priori (2000; 2009; 2011; 2012); dos jornalistas e escritores Oikawa (2011) e Diego Antonelli (2016); do escritor Osvaldo Heller da Silva (2006) e dos escritos da polícia militar do Paraná, a partir das anotações do Capitão Rosa Filho (2003). O resultado revela a possiblidade desse material como conteúdo de História Local e Regional, e da importância de ser revelado aos interessados pela temática, pois, a Guerra de Porecatu foi um movimento de resistência onde trabalhadores foram explorados e expulsos, servindo ao capital, à política da época e aos poderosos latifundiários.

Palavras-Chave: Guerra de Porecatu, História Regional, Paraná, Partido Comunista, Movimentos Sociais.

\section{INTRODUÇÃO}

Este artigo, baseado em revisão bibliográfica, teve como objetivo principal apresentar os motivos e os resultados da Revolta Camponesa de Porecatu.

A História do Paraná conta que, em meados de 1940, em busca de um novo Eldorado, muitos homens e mulheres se dirigiram ao Vale do Paranapanema, ao norte do Estado, atraídos pela oferta que o interventor Manoel Ribas fazia para aqueles que desejassem colonizar as terras devolutas daquela região e ali tomassem posse dela.

No entanto, diante da ganância de grileiros, estes camponeses remeteram-se à uma guerrilha, logo em 1942, organizando-se em Ligas[3], para lutarem pela posse definitiva dessas terras (ANTONELLI, 2016). E foi neste período que estes posseiros, apoiados pelo Partido Comunista Brasileiro-PCB, pegaram em armas, em um movimento de resistência, pisando em sangue, para defenderem o que lhes havia sido proposto, ou seja, a ideia de que se suas famílias colonizassem e desenvolvessem seu trabalho naquela localidade, Ihes seriam concedidos os títulos da propriedade da terra. Mas, não foi bem assim que tudo aconteceu. Ali desencadeou-se o triste evento 
conhecido como Guerra ou Guerrilha de Porecatu, um movimento de revoltosos ocorrido no final da década de 1940 e início da de 1950, onde grileiros se posicionaram contra os posseiros, e se tornaram os principais personagens desse conflito de terras no Paraná, no Século XX (PRIORI, 2011).

Esta luta pela terra constitui-se em temática atual em todo território brasileiro, e o que pode parecer estar ocorrendo distante da regionalidade onde habita o leitor, na verdade também foi acontecimento da história local. Importante, portanto, para trabalhar a questão da identidade dos sujeitos históricos e garantir a apropriação do conhecimento, embasados nos resultados das pesquisas e relatos selecionados, valorizando o patrimônio histórico da localidade.

Este trabalho de pesquisa, baseado em levantamento bibliográfico catalogado em sites confiáveis, obras impressas e periódicos, teve por objetivo contar o que a História Regional já levantou a respeito desse período da História do Paraná, trazendo à tona referências como as obras do professor doutor Angelo Priori (2000; 2009; 2011; 2012); dos jornalistas e escritores Oikawa (2011) e Diego Antonelli (2016); do escritor Osvaldo Heller da Silva (2006) e dos escritos do Capitão Rosa Filho (2003) que traz a visão a polícia militar do Paraná sobre o evento.

A amplitude conceitual deste levantamento teórico passou pela abordagem do conceito de História Regional que, de acordo com Cerri (apud ALEGRO et al., 2013), é aquela considerada responsável pelo estudo da circunscrição de cada cidade, neste caso, do município de Porecatu e sua formação; bem como, interessou-se pela análise das questões agrárias brasileiras para tratar daquele momento específico. Também pensou a abrangência da história local que se reporta às pequenas localidades, que nem sempre é escrita por historiadores, e que sofrem o descaso dos conteúdos escolares (SCHIMIDT; CAINELLI, 2004).

Em seu primeiro momento a pesquisa apresenta o Novo Eldorado[4], sua localização geográfica e cronológica, trazendo à tona dados que precisam ser rememorados pela História e que estão cravados na memória coletiva, embora esquecidos pelos livros escolares, em sua grande medida. 
$\mathrm{Na}$ sequência relata o que os referenciais supracitados consideraram os pontos mais importantes desse confronto, destacando a participação do Partido Comunista Brasileiro que ficou ladeado a um dos protagonistas dessa guerra: os posseiros. Chega-se, depois, à conclusão que, embora tenha havido enorme injustiça contra os que sonharam o Eldorado, os latifundiários se apropriaram do apoio político do Estado, e de ferramentas escusas, como documentos falsos e apoio de alguns membros da magistratura e perpetuaram seus nomes, como aqueles que teriam alavancado o progresso para a região da guerrilha e para a cidade de Porecatu. E, conclui-se que o Partido Comunista Brasileiro fez daquele momento beligerante um laboratório de luta armada o campo, mas, posteriormente, no decorrer de todo este período até os dias atuais, esqueceram-se de contar a sequência de erros avaliados na experiência no Paraná[5].

Tal conflito, ocorrido nas décadas de 40 e 50, teve repercussão nacional, no entanto, o tema não é recorrente nas aulas de História, num lapso de memória, considerado por Osvaldo Heller da Silva (2006) como uma "amnésia historiográfica" e, por isso, merece ser rememorado a tempo de considerar episódios que foram responsáveis pela formação social e cultural de um dos Estados mais promissores da federação, cujo qual, em sua colonização agrária sofreu com diferentes experiências, a exemplo do conflito de classes (posseiros e fazendeiros) que levou à Revolta, Guerra ou Guerrilha de Porecatu.

Para tratar de forma organizada do resultado desta pesquisa, estabeleceu-se a redação em três momentos distintos, definidos por tópicos, para melhor encaminhar o leitor ao atingimento dos objetivos estabelecidos.

O tópico um ficou reservado à explicação da política daquele momento, conhecida como Homestead Act [6] e ao esclarecimento de onde estava localizado o Eldorado do Paraná. A seguir, do Conflito e da Atuação do Partido Comunista Brasileiro como apoio aos posseiros e, em seguida, falou-se, a respeito o que se aprende com as memórias da Revolta de Porecatu. 


\section{A POLÍTICA HOMESTEAD ACT PARA O ELDORADO DO PARANÁ}

Era 1940 correu a notícia de que havia 120 mil hectares de terras devolutas ao norte do Estado do Paraná (FELISMINO, 1985). Centenas de famílias foram atraídas por essa promessa, e partiram para tal localidade, na intenção de povoar a produzir.

Estas terras vazias, inabitadas, era o Eldorado esperando para ser cultivado, colonizado e semeado pelas famílias que saíram de Minas Gerais, São Paulo, região nordeste e de outras partes do Estado do Paraná, na confiança de que ali criariam seus filhos e conseguiriam manter sua posse legal (ANTONELLI, 2006).

Figura 1- Localização das terras devolutas- Mapa atual

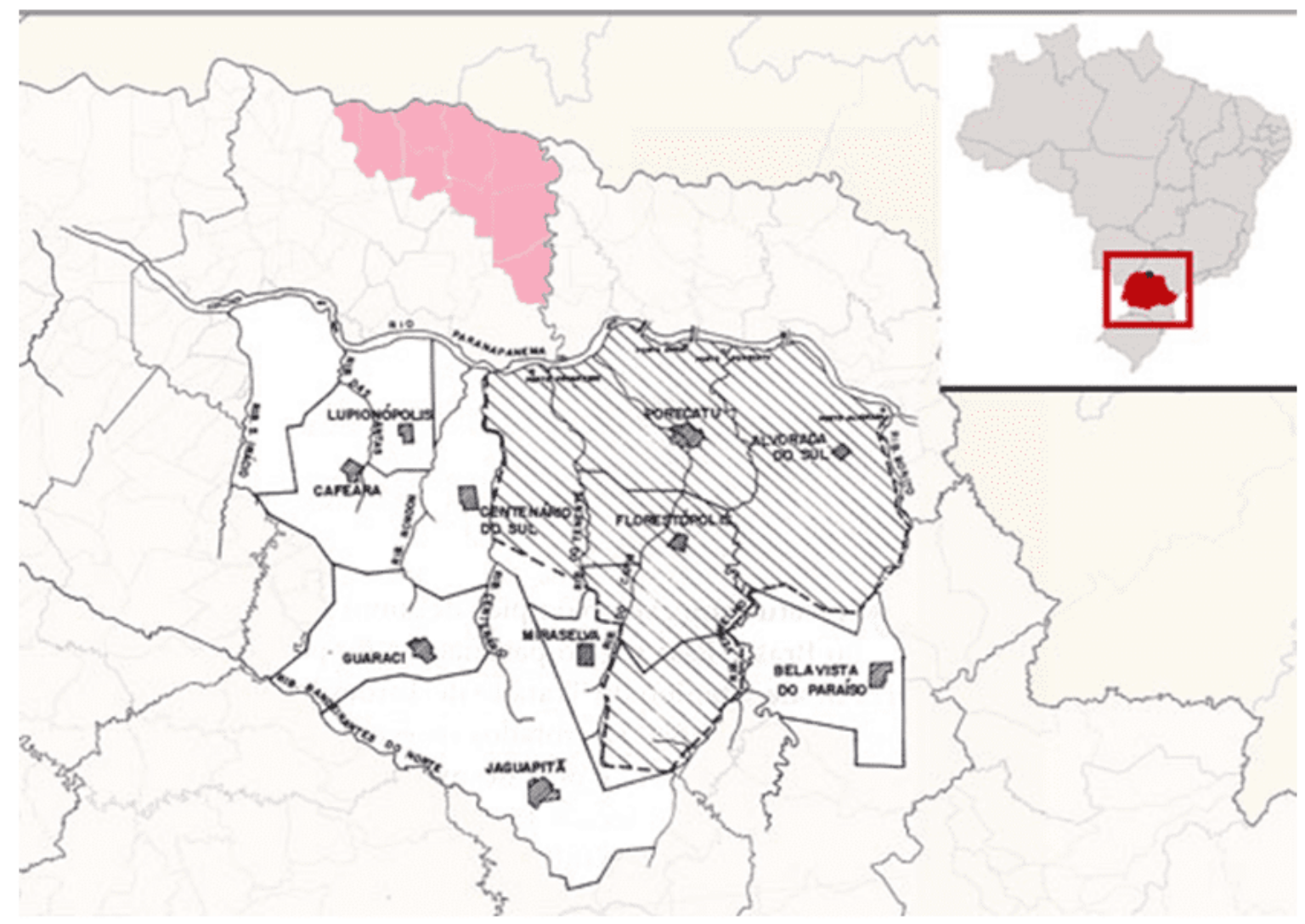

Fonte: Arruda (2012)

"Era uma área coberta pela Mata Atlântica", conta Nossa (2010, p. 14). O Eldorado ficava na região entre os Rios Paranapanema e Centenário, ao norte do Estado do Paraná, divisa com São Paulo, na região das cidades de Porecatu, Centenário do Sul, 
Jaguapitã e Guaraci, localização indicada pela companhia de desbravamento e colonização do interventor Manoel Ribas (FELISMINO, 1985).

Ainda sobre o local deste Eldorado, o historiador Angelo Priori (2009, p.2) esclarece:

A região denominada como Porecatu está encravada no extremo norte do Estado do Paraná, situada no Vale do Paranapanema. A colonização dessa região começou no final dos anos de 1930, no contexto da nova política de terras implementada pelo Governo Vargas e conhecida como Marcha para o Oeste.

O atrativo desta campanha governamental era o de conseguir melhores condições de vida, pois, a partir da posse de uma parcela destas terras, radicando-se naquele local, as famílias teriam a chance de organizar a propriedade da terra estruturando-a conforme determinado, ou seja, "através da cultura do café, de culturas alimentares e da criação de porcos" (PRIORI, 2003, p,1).

Vale lembrar que o Estado do Paraná tinha o domínio das terras devolutas e do reconhecimento da legitimidade das posses concedidas por sesmarias ou outras concessões, e que "no Paraná, o interventor Manoel Ribas, inspirado no Homestead Act, de Abraham Lincoln", conclamou quem estivesse interessado a ocupar até 200 hectares de mata "pelo preço mínimo de 18 mil-réis o hectare"[7], conta Oikawa (2011, p.15).

De acordo com Oiakwa (2011, p.27-28):

Porecatu encontra-se [...] localizada a $22^{\circ} 45^{\prime} 21^{\prime \prime}$ S $51^{\circ} \mathrm{ss}$ ' $44^{\prime \prime} \circ$ às margens do rio Paranapanema. Tem uma área de $291,665 \mathrm{Km}$ e faz divisa ao norte com os municípios de Taciba e Narandiba no Estado de São Paulo, ao sul com os municípios de Florestópolis, a leste com Alvorada do Sul e a oeste com Centenário do Sul [...] A região denominada como Porecatu, desde os primórdios do Brasil Colônia, é formada atualmente pelos municípios de Porecatu, Alvorada do Sul, Florestópolis, Mirasselva, Centenário do Sul, Lupionópolis, Cafeara, Guaraci e Jaguapitã.

Ainda hoje, sabe-se que esta região consta de um solo fértil de terra roxa, mas, que já não mais descansa sob as sombras das verdes matas, mas, sim, é pisado por 
trabalhadores rurais, especialmente da cana-de-açúcar e da soja, culturas que tomaram o lugar do café.

Priori (2011, p. 19) esclarece que: "O Paraná do século XIX era uma província quase que exclusivamente habitada na faixa litorânea e na região dos campos gerais". Foi a Lei de Terras de 1850 que possibilitou o acesso às terras devolutas, por ocupação, e o acesso às propriedades a partir, exclusivamente, da compra. O que não inibiu o governo do Paraná a alienar suas terras na extensão de seus domínios àqueles que "se propusessem, pelo trabalho, torná-las uteis ou então, fazer algum serviço que viesse beneficiar a comunidade" (PRIORI, 2011, p.22).

Nesta ocasião, "o Estado, sem muitos recursos financeiros, repassou grandes quantidade de terras a empresas privadas [...]" e neste processo de concessão de terras públicas, foi formulada a política de colonização, com o objetivo de fundar núcleos coloniais, "destinados a imigrantes estrangeiros" (PRIORI, 2011, p.23).

A holding Paraná Plantation Limited criou a Companhia de Terras Norte do Paraná, e esta organizou e revendeu 515 mil alqueires de terras, num ambicioso processo de colonização do centro-sul do país, com propagandas que se estendiam para Europa e Japão. Mas, em 1938 o Interventor do Paraná, Manuel Ribas, apontou uma extensão do processo fraudulento dessas concessões às tais empresas particulares (PRIORI, 2011).

Houve de fato as concessões às colonizadoras e depois elas foram revogadas porque o governo do Paraná percebeu que nem todas as empresas colonizadoras estavam atuando no processo imobiliário, o que fez com que muitas fossem cassadas.

Todas estas etapas acabaram sendo desdobramentos da Lei de Terras, Lei 601/1850[8], onde o processo de concessão de terras públicas para empresa privada gerava especulações e transações erradas, propiciando embates e violência nestas áreas (PRIORI, 2011).

A proposta política da Marcha para o Oeste, do governo federal, objetivava uma reorientação agrária, visando a intensificação da produção sob a intervenção do 
Estado, e o Paraná não se furtou a elaborar legislação para esse processo agrário, após os anos 30 (PRIORI, 2000).

No início dos anos de 1940, a partir de Decreto, qualquer pessoa podia solicitar um lote de terras com 200 hectares, devendo depois "obedecer apenas a uma regra: derrubar a floresta, plantar, produzir e viver na posse durante seis anos" (OIKAWA, 2011, p.51). Ao final deste período poderia requerer o título definitivo da propriedade.

Priori (apud OIKAWA, 2011, p.51) informa que para ter direito definitivo sobre o lote o comprador deveria apresentar, no prazo de dois anos, documentos que comprovassem a existência de moradia habitual e cultura efetiva, além de realizar o pagamento integral de sua terra.

Mas, tudo isso, era válido, afinal, estavam em busca da "terra prometida" (grifo meu). No entanto, para o tal Eldorado, brilharam também os olhos dos gananciosos. E a política mal feita do Estado permitiu que o direito de propriedade fosse superposto por dois grupos: o dos posseiros que foram atraídos pelo desejo de se tornarem donos legítimos desse pedaço de chão e o daqueles que revalidaram os títulos da exconcessão e seus compradores (muitas vezes grandes fazendeiros, já capacitados para a mecanização agrícola e para o cultivo dos melhores tipos de café em grande escala) (OIKAWA, 2011).

Dentre estes grandes fazendeiros, que compraram terras ocupadas por posseiros, Oikawa (2011) destaca os da família Lunardelli, que adquiriram grandes lotes, a partir de contratos que thes garantiam que as terras estavam desocupadas, desconsiderando a demarcação feita por famílias ou grupos familiares dos posseantes.

No entanto, não apenas a família Lunardelli, outras famílias também tomaram posse baseadas nessa forma escusa, como relata Antonelli (2016, p.76): "Pelo menos 10 grandes grileiros forjavam documentos falsos e atestavam que os lotes já tinham donos". 
Este foi, pois, o cenário propício para o desenrolar de uma trama histórica, de sangue e suor, que aconteceu no Vale do Paranapanema, a qual fez com que os posseiros e suas famílias fossem obrigados a pisar em sangue para deixar vivo o sonho que ali os tinha trazido.

Destaque-se, no entanto, que o conflito só aconteceu como forma de defesa, pois, os posseiros e suas famílias vinham sofrendo reprimendas violentas dos policiais e pistoleiros, a mando dos grileiros de terras e dos grandes proprietários, bem como sofriam com as decisões judiciais que lhes obrigavam a abandonar suas posses de terra (PRIORI, 2011).

Dessa forma, privados de seus direitos e de sua esperança em ser dono daquela posse, sentindo que iriam ser expulsos da terra, procuraram se organizar e reagir, formulando, a partir da Liga Camponesa, argumentos de defesa que lhes permitisse conservar a conquista do Eldorado. Afinal havia sido esta a política anunciada primeiramente por Manoel Ribas e os posseiros queriam a terra e não o poder, como prezavam os grileiros/fazendeiros e políticos da época.

\subsection{O CONFLITO E A ATUAÇÃO DO PARTIDO COMUNISTA BRASILEIRO}

Diante do anúncio de que havia terras devolutas, de primeira qualidade, na região de Porecatu, foram muitos os pequenos agricultores que acreditaram na existência delas e vieram para o local. Mas, também não foram poucos os especuladores, grandes proprietários que, sabendo da existência dessas terras vazias, avançaram sobre elas desordenadamente, e foi assim que estas áreas se transformaram num caos (SILVA, 1996).

No site da Fundação Dinarco Reis (2016) lê-se que:

Em 1934, o interventor Manuel Ribas (1932-1945) anulou a concessão e loteou as terras, a preço barato, para quem quisesse trabalhar. Como tantos outros antes dele, José Bilar ("Espanhol") chegou à região em 1940. Cito outros: Francisco Lourenço Figueiredo ("Chico Quiabo"), 
Herculano Alves de Barros e Lázaro Bueno de Carvalho (“Lazão"). A maioria comprou sua terra, outros eram "grileiros", mas de boa-fé.

O interventor Manoel Ribas havia incentivado a derrubada das matas e o cultivo da terra em grande escala com vistas ao progresso do norte do Paraná, e os posseiros se dirigiram para lá confiantes no incentivo oficial, de boa-fé, acreditando que toda aquela área ainda não tinha sido dada com título definitivo a ninguém (ROSA FILHO, 2001/2004).

Houve, então, uma corrida alucinada para aquisição destas terras devolutas, que eram concedidas a partir de simples requerimento e pagamento de taxas insignificantes. Os prazos dos editais foram reduzidos e o preço do hectare era ficado de acordo com a conveniência.

A este respeito, Rosa Filho (2001/2004, p.17) ainda revela que

[...] os prazos para editais foram reduzidos de 30 para 10 dias; os prazos para as vistas, de 10 dias foram para 48 horas; os prazos para pagamento, de 4 meses para 30 dias; o preço do hectare fixado ao sabor das conveniências; as ordens de urgência na localização e ocupação, dadas sem nenhuma atenção de medição e demarcação; chefes de serviço de demarcação no interior eram chamados à Capital para acertar com os próprios interessados a delimitação de suas áreas.

Quando chegou ao final do governo Lupion, a negociata estava instaurada, tanto que o Departamento de Terras funcionava até à noite em quartos de hotéis em Curitiba, e fora deles fervilhavam vendedores de requerimentos de terras já despachados, com ou sem localização, ou com ou sem prestação paga, e outras vezes em nomes de falecidos, "por 30, 40 ou 50 mil cruzeiros", lembra Rosa Filho (2001/2004, p.17).

Pode-se inferir também que, no início, com a concessão de terras, muitas companhias particulares compraram vastas áreas, quando da iniciativa da colonização dirigida. $O$ Estado transferia a elas os encargos e a responsabilidade da colonização, mas, a partir disso, acabou por serem formados imensos latifúndios improdutivos, o que fez com que o próprio Estado incentivasse novamente a colonização para ocupação e desenvolvimento. Isso gerou todo esse drama. 
Aconteceu, porém, que, com a valorização dos preços do café, com a substituição da interventoria pelo Governo de Moisés Lupion, estas terras do norte do Estado, tornaram-se alvos de negócios escusos e ali aconteceu uma verdadeira corrida em busca de títulos definitivos daquelas tão férteis terras vermelhas, que acabaram sendo concedidas aos "apaniguados do governador mediante simples requerimento a pagamento de taxas ínfimas" (ROSA FILHO, 2003, p. 17).

A Fundação Dinarco Reis (FDR, 2016, p.2) relembra que:

Manuel Ribas comprometera-se com os camponeses. Entretanto, o quadro mudou com a posse de Lupion (12/03/1947), ex-procurador de Jeremias Lunardelli, o 'Rei do Café'. Lupion assinou um decreto à feição da grilagem de Lunardelli e pôs à sua disposição a Força Pública para obrigar os camponeses a 'abandonarem' as terras cuja propriedade, depois, iria requerer.

Antonelli (2016, p. 77) confirma tal informação informando que: "Grupos que estavam à sombra de Lupion chegaram ao ponto de falsificar mapas para ter o lote dos posseiros".

Tudo isso acabou resultando em conflito, pois, havia a preterição dos direitos dos posseiros, cujos nomes foram sendo, literalmente, riscados das plantas e das folhas dos processos, com a expedição de títulos definitivos duplicados, onde o Governo revendia aquilo que já havia vendido a outro (ROSA FILHO, 2001/2004).

Houve muita confusão, por isso, Rosa Filho (2001/2004) conta que houve inclusive, o arrancamento de folhas dos processos, tendo se chegado ao cúmulo da venda de uma área superior a 130 mil alqueires de terra que não existia no território paranaense.

Diante disso, os posseiros precisavam legalizar a posse de suas terras, sair do isolamento e defender seus interesses, haviam derrubado as matas, ocupado a terra, feito benfeitorias, preparado o solo e plantado, valorizando a terra com tal ocupação e então os fazendeiros buscavam meios legais para expulsá-los de lá, ficando com os benefícios. Por isso, a partir dessa ocupação caótica, iniciou-se o conflito em torno da posse dessas terras, que permitiu "deflagrar o processo de implantação do Partido 
Comunista Brasileiro, no campo, e modelar as primeiras formas de representação coletiva do campesinato, as de ligas camponesas" (SILVA, 2006, p.19).

Oikawa (2011, p. 95) lembra que:

O termo camponês começa a ser usado em Porecatu pela primeira vez no Brasil para designar o trabalhador do campo, proprietário ou não, que desenvolva a agricultura familiar. É a transposição da linguagem da Internacional Comunista, baseada nas experiências soviética, europeia e da América espanhola [...]. Em Porecatu a nova palavra - camponês, causa surpresa e estranheza aos proprietários rurais e também a imprensa.

Estes camponeses precisavam de ajuda para enfrentar os jagunços dos fazendeiros, os farsantes donos de cartórios, os juízes corruptos e a polícia militar, e para essa finalidade foi que eles buscaram a ajuda do Partido Comunista Brasileiro e, em 1948, decidiram armarem-se para combaterem (FDR, 2016).

Os posseiros não tinham a quem recorrer, haja vista que o governo do Estado foi quem os colocou nesta situação tendo divulgado uma notícia que depois se tornou uma falácia.

Priori (2011, p 63) lembra que Eric Hobsbawn (1998) pontua três tipos de ocupação de terras:

1) quando a terra pertence aos camponeses mas foi alienada, legalmente ou não, por alguém, de um modo que os camponeses não reconheçam esse caso como válido; 2) quando a terra é reivindicada simultaneamente por camponeses ou grandes proprietários, sendo que geralmente a terra é pública e de domínio do Estado; 3) quando a terra pertence a alguém, comprovadamente ou legalmente, mas ela é expropriada por outrem.

Com esta observação, afere-se que os dois primeiros casos são apropriados para o conflito de Porecatu, haja vista os principais personagens da trama: posseiros, grileiros e jagunços. Mas, é no segundo tipo que a Revolta se encaixa, pois, a terra é reivindicada, ao mesmo tempo, pelos camponeses e pelos supostos proprietários. 
Nilson Monteiro Menezes (2015, p. 148) referenda a história já anotada resumindo-a da seguinte forma: "A ocupação das terras devolutas, que começou com a chegada de 300 posseiros em 1940 e terminou com cerca de 3 mil em litígio em 1951, acabou registrando o reassentamento de 380 famílias na região".

Mas, há versões mais detalhadas que acusam, especialmente o Governo do Estado de ser sido omisso aos primeiros momentos de resistência dos posseiros, quando a luta avançava, logo após a posse de Moisés Lupion (1946-1950), que distribuiu documentos das terras a grandes fazendeiros provocando a revolta e a resistência aos mandados de reintegração de posse, pois, afinal, os posseiros já estavam ali no prazo determinado para conseguirem os títulos definitivos daquelas terras.

Pires et al (2010, p. 1), a respeito do momento em que teve origem o início da revolta, contam que:

Em 1946, Moisés Lupion assumiu o Governo do Paraná e iniciou novo processo de loteamento, dividindo a região em glebas extensas, que foram vendidas para grandes fazendeiros. As terras vendidas, contudo, eram aquelas ocupadas pelos posseiros, que Lupion considerou devolutas. É a partir deste momento que a insatisfação de ambos os lados, os posseiros e latifundiários, se agrava, iniciando o conflito.

Diante da pressão feita pelos fazendeiros, grileiros e a própria polícia, no sentido de os posseiros desocuparem as terras que eles tinham lavrado e confiado serem suas, o Partido Comunista Brasileiro foi quem colaborou com a organização da resistência. Afinal, já havia ali o conflito, mas, os posseiros estavam em desvantagem e vinham recebendo ameaças contra suas vidas.

Antes de pegarem em armas, os posseiros foram moderados, entraram com recursos judiciais e solicitaram ação do governo, mas, enquanto o governo se calava, os grandes fazendeiros se apoiaram em ações de jagunços e da força policial para invadirem diversas propriedades.

É verdade também que o Governador Bento Munhoz da Rocha Neto, tendo assumido logo após Moises Lupion, tentou negociar pacificamente com os posseiros, propondoIhes o reassentamento por meio de um decreto. Proposta esta que o PCB chamou de 
demagógica, pois acreditavam que o governador teria sido obrigado a elaborar tal decreto para dar uma satisfação ao público, visto que tal decreto foi baixado especificamente para os municípios de Rolândia, Jaguapitã e Porecatu, onde havia menos terras a serem desapropriadas (MENEZES, 2015).

Rosa Filho (2001/2004, p17) corrobora escrevendo que:

[...] assumindo o governo, Bento Munhoz da Rocha Neto prometeu legalizar a situação. No entanto, entre aqueles que chegaram ao norte do Paraná em busca de terra e dinheiro, vieram os malfeitores [...] membros do Partido Comunista Brasileiro, que quiseram aproveitar da situação de geral confusão e avançar em terreno alheio. Ali fincaram o pé e, desde então, se mantiveram fiéis ao programa do seu partido.

Os posseiros que se recusavam a sair de suas terras também pegaram em armas e, para apoiá-los, entrou em cena o Partido Comunista Brasileiro, fornecendo-Ihes armamento e treinamento militar (PIRES et al, 2010)

Até então, nos atos de violência, os rebeldes se utilizavam apenas das armas que possuíam, ou seja de seus instrumentos de trabalho, mas, aceitando a direção do PCB, quanto então este partido propôs a constituição de bandos armados de resistência, os posseiros rebeldes acabaram concordando, procedendo a formação de grupos armados e o treinamento de resistência física, era o ano de 1948. Também foi por orientação do PCB que se formaram as Ligas Camponesas. Tais Ligas tiveram papel importante de solidariedade ao movimento, pois, os posseiros acabaram obtendo apoio dos comerciantes e mascates para transmitirem informações importantes e angariaram simpatizantes em todo país (BARROS, 1989).

Também vale considerar a anotação de Oikawa (2011, p.166) que esclarece: "[...] os conflitos não foram criados pelo PCB, mas, pelos desmandos e desvios de sucessivas políticas de colonização adotadas pelos governos para a região".

Convém considerar o que relata Osvaldo Heller da Silva (2006, p. 59):

Naquela época, o Partido Comunista tinha uma penetração limitada nos rincões do Paraná setentrional, como em todo o resto do país. Havia militantes isolados em Porecatu; alguns comitês locais nos municípios 
de Jaguapitã, Centenário, Porecatu, Arapongas, Rolândia, Cambé, Ibiporã, Cambará, Sertanópolis, Marrecas, Bandeirantes, Cornélio Procópio e Apucarana; um comitê Regional em Londrina e um outro de âmbito estadual, em Curitiba.

A própria concepção de comunismo era muito particular, e os próprios posseiros, mesmo tendo aceitado ajuda, chegavam negar sua interação com esse movimento, pois, havia naquele momento uma ideologia anticomunista que já se fazia presente na população. E foram os militantes de Jaguapitã que tiveram as primeiras conversas de fortalecimento dos laços com o Partido. Sabe-se que em outubro de 1948, os representantes dos posseiros de Porecatu, viajaram ao Rio de Janeiro para se encontrarem como o dirigente nacional do "partidão" (grifo do autor) e lá elaboraram um documento que deveria ser entregue às autoridades federais. $E$, a partir daí, o Partidão decidiu atuar efetivamente em apoio aos posseiros do norte do Paraná, visando tomar a frente do movimento de resistência, enviando emissários, constantemente, à região do conflito (SILVA, 2016).

"O conflito foi terreno fértil de descontentamento social, onde os comunistas lançaram a semeadura de um comunismo rural [...] com a incumbência de orientar a doutrinação soviética dos posseiros e de Ihes proporcionar assistência na resistência, lembra Rosa Filho (2001/2004, p.18)

Priori (2009, p.5) enfatiza que "A decisão do Partido Comunista Brasileiro de assumir a organização da luta armada no Norte do Paraná foi concretizada formalmente em novembro de 1948 [...]".

Foi assim que no final dos anos quarenta o PCB fez circular a proposta de um Estatuto que tinha como objetivo ampliar a discussão sobre a formação das Ligas Camponesas onde conclamava os posseiros a lutarem por quesitos essenciais para suas vidas como: créditos bancários, preços para produção, melhores salários, etc (PRIORI, 2009).

Heller da Silva (2009 b, p.111) conclui que: 
Porecatu seria mais um entre os conflitos pela posse fundiária não fosse a entrada em cena dos comunistas, [...]. Esse conflito permitiu a aparição dos primeiros organismos de tipo sindical a enquadrar o campesinato: as Ligas Camponesas.

O que o autor indica é que, no rastro de Porecatu, muitos sindicatos se alastraram pelo norte do Estado e se tornaram a base de todo aparato sindical futuro, não apenas no Paraná, mas, em todo Brasil. Esse, com certeza, foi um fruto daquela revolta.

A verdade é que, quando os posseiros não tiveram cumpridas as promessas feias pelo Governo, o PCB encontrou ali ótima oportunidade de se instalar como partido, o que não impediu que, no decorrer da história, se calassem a respeito dos episódios ocorridos em Porecatu, mantendo silêncio a respeito da participação do Partido na Revolta, haja vista que os efeitos causados em suas lideranças devido ao mal-estar que causou-Ihes a delação de "um certo capitão Carlos"[9] (grifo meu).

Nem todos os posseiros aliados ao PCB foram vistos com bons olhos. A Delegacia de Ordem Política e Social- DOPS, através de seus delegados instalaram um regime preventivo contra as manifestações e passaram a fazer diligências na região de Porecatu, espalhando um projeto de medo a fim de debilitar a organização dos posseiros e seus aliados comunistas e, "pode-se afirmar, inclusive, que a estratégia foi bem sucedida, já quem em um prazo de dez meses o órgão conseguiu acabar com a resistência camponesa" (PRIORI, 2011, p.173).

O DOPS propunha a deserção, como estratégia para que os convencidos abandonassem a luta armada e passassem a serem informantes do processo criminal instalado. $E$ foi nessa fase que muitos posseiros foram presos, sendo que a última e intensa ação policial durou dois meses e foi instalada em 21 de junho de 1951, utilizando-se de um processo de varredura da região conflagrada, fazendo vistoria em diversos acampamentos e chegando as margens do Paranapanema sem qualquer resistência (PRIORI, 2011).

Foi assim que, em meados de julho de 1951, após esta operação de varredura o Governo do Estado acionou a Comissão de Terras para assentar os camponeses em colônias de Centenário, Iporã, Campo Mourão e Paranavaí, recebendo lotes de 5 a 
20 alqueires de terras de menor qualidade, porque as terras de primeira ficaram mesmo em posse dos fazendeiros (PRIORI, 2011).

\subsection{O QUE SE APRENDE COM AS MEMÓRIAS DA REVOLTA DE PORECATU}

Existe pouca divulgação dos conflitos agrários ocorridos em solos paranaenses e a Revolta ou Guerra de Porecatu é um desses casos importantes que necessitam de aproximação do estudioso para uma luta que foi protagonizada por camponeses pobres e sonhadores que recorreram a uma proposta estadual de colonização, mas, que acabaram sendo engolidos pela expansão do capitalismo rural.

Na Revolta Camponesa de Porecatu, os camponeses posseiros foram expulsos, e suas terras foram apropriadas por latifundiários, em um contexto histórico pouco divulgado, e onde o mote do conflito não era o poder, mas, a posse legal da terra.

Leocádio e Ivano (2010, p. 1180) lembram que, no caso da Revolta de Porecatu:

Devemos levar em consideração o fato de que toda uma memória sobre a guerra foi silenciada propositalmente, jogada ao ostracismo do esquecimento justamente para que os erros e equívocos cometidos pelo PCB [...] não viessem a tona para serem devidamente julgados. Tentouse manipular, indiscriminadamente, a memória daqueles que viveram e sofreram as amarguras da traição. Por acreditarem nas falácias do "Partidão", ganharam como presente o limbo do esquecimento; foram desprezados por um Partido que optou em se manter integro em detrimento à memória daqueles que dedicaram sua vida em prol de uma ideologia que se mostrou, quando testada, egoísta ao extremo.

Mas, a memória dos envolvidos não pode ser silenciada desta forma e esquecida. Existem fontes que se preocupam com tais verdades e instrumentalizam o interessado a saber e investigar os fatos.

Para Le Goff (1996, p. 477):

A memória, onde cresce a história, que por sua vez a alimenta, procura salvar o passado para servir o presente e o futuro. Devemos trabalhar 
de forma que a memória coletiva sirva para a libertação e não para a servidão dos homens.

É preciso dar ampla valorização a história da Revolta de Porecatu, fazendo com que ela seja localizada num painel de conflitos do Norte do Paraná, onde a ocupação e construção do território não foram pacíficas como apontam alguns agentes da história.

Tratar dos termos como: terras devolutas, posseiros e grileiros, dentre outros, já se torna um passo para discutir os sobre esta luta pela terra, na Revolta de Porecatu.

Allegro et al (2008, p.5) conta, por exemplo que a Companhia de Terras Norte do Paraná -CNTP, colonizadora da região, publicou um folheto intitulado Norte do Paraná, onde apresentava a região como: "[...] um Eldorado, onde não há minas de ouro mas onde se faz ouro de tudo". No entanto, não foi a CTNP colonizou Porecatu, tratava-se de uma publicação que afirmava a imagem de uma Terra de Promissão, com ideia de progresso, mas, e sobre os conflitos para a conquista dessa Canãa, quem escreveu?

As autoras falam de diversos álbuns que comemoram efemérides, fazem propaganda, elevam biografias, cantam a fertilidade da terra, inclusive destacando que dois repórteres que andavam com Bento Munhoz da Rocha teriam escrito que teria havido a resolução dos conflitos ocorridos em Porecatu. Trata-se sempre de um discurso de felicidade em detrimento à violência daquele momento.

\section{Então como fazer?}

É necessário que a História discuta o uso da violência nestes e em todos os conflitos agrários, seja como ação ou reação; discuta a participação política neste meio, como no caso do PCB na Revolta Camponesa de Porecatu, pesando suas ações, influências e objetivos. É importante que a Revolta Camponesa de Porecatu seja situada da história de lutas pela terra, fazendo perceber sua complexidade e a continuidade dos conflitos fundiários no Brasil. Afinal como andam as políticas de distribuição de terras e a reforma agrária no Brasil? 
A Revolta de Porecatu precisa levar a esta avaliação da questão agrária, da ocupação do solo brasileiro, da estrutura fundiária e das lutas e conquistas já alcançadas neste país.

\section{CONSIDERAÇÕES FINAIS}

As versões a respeito da Revolta ou Guerrilha de Porecatu são, em sua maioria, defensoras dos posseiros e acusadoras do Estado. No entanto, foi possível verificar que, muito embora os personagens envolvidos têm visões diferentes do resultado daquele momento belicoso. Para o PCB teria sido mais que um erro, mas, um verdadeiro fracasso; para os posseiros uma vitória, embora não se possa concordar em absoluto, visto que, a terra pela qual eles lutaram não se converteu em título de posse, mas, eles concordaram em aceitar lotes legalizados em outras localidades bem mais distantes, como em Paranavaí, Iporã e Campo Mourão, lembra Priori (2011). Para os grileiros/ fazendeiros e apaniguados do Estado, a este, sim, valeram cada gota de sangue derramado pelos jagunços para fazer valer os documentos que thes foram concedidos e para gravar seus nomes na História de Porecatu como fazedores de progresso e construtores do futuro.

Por essa, dentre outras razões mais particulares de cada um que venha ter em mãos o material aqui consultado, é que exige-se que a História Regional faça valer a memória coletiva, de forma que todos possam, livremente, tomar partido nesta história onde os pés dos trabalhadores pisaram em sangue em busca de um Novo Eldorado.

Essa temática é muito importante, pois, a Revolta de Porecatu se compara com Canudos, Contestado, etc, mas, estas outras têm destaque livros didáticos e bibliografias, o que precisa ser feito pela História Local com este movimento de resistência, onde os trabalhadores acabam servindo ao capital e depois são expulsos e realocados em outros locais conforme mandam os poderosos. 


\section{REFERÊNCIAS}

ANTONELLI, Diego. Terra Roxa de Sangue. Reclamando [on line]. Publicado em 07/12/2013. http://reclamando.com.br/?system=news\&action=read\&id=42321\&eid=142> Acesso em 03 set. 2017.

. Paraná: uma história. Curitiba: Arte \& Letra, 2016.

ARRUDA, Fausto. Porecatu e a Revolução Democrática. Rev. A Nova Democracia. Ano X, no 89, maio de 2012. Disponível em:< http://anovademocracia.com.br/no89/3974-porecatu-e-a-revolucao-democratica> Acesso em 12 maio de 2017.

BARROS, Vania Aparecida de. A Guerra de Porecatu. Projeto Folhas. Londrina, 1989.

Disponível

em:< http://www.gestaoescolar.diaadia.pr.gov.br/arquivos/File/producoes_pde/md_vania_a parecida_barros.pdf>Acesso em 12 set. 2016.

FELISMINO, Pedro Paulo. A guerra de Porecatu: a história do movimento armado pela posse da terra que sacudiu o Norte do Paraná nas décadas de 40 e 50. Folha de Londrina, 14-28 jul. 1985.

FERREIRA, Jorge. A Guerra de Porecatu. Revista O Cruzeiro. Ed. de 14 de julho de 1951. Hemeroteca da Biblioteca Digital do Brasil. XX - 112. . Disponível em:< http://memoria.bn.br/DocReader/docreader.aspx?bib=003581\&pasta=ano\%20195\&p esq=GUERRA\%20DE\%20PORECATU> Acesso em 13 jun. 2017.

FDR. FUNDAÇÃO DINARCO REIS. Saldanha e Porecatu. Rio de Janeiro: PCB, 15/06/2016.

Disponível

em:< https://pcb.org.br/fdr/index.php?option=com_content\&view=article\&id=286:saldanhae-porecatu\&catid=6:memoria-pcb> Acesso em: 13 jan. 2017.

LEAL, José. Sangue na Terra Proibida. Rebelião no Paraná. Revista O Cruzeiro. Ed. 8, 9 de dezembro de 1950. Hemeroteca da Biblioteca Digital do Brasil. 58-96. . 
Disponível

em:< http://memoria.bn.br/DocReader/docreader.aspx?bib=003581\&pasta=ano\%20195\&p esq=porecatu> Acesso em: 2 jun. 2017.

LE GOFF, Jacques. Memória. In: História e Memória. Campinas, SP: Editora da UNICAMP, 1996, p. 423-477.

LEOCÁDIO, Leandro César. IVANO, Rogério. Guerra de Porecatu e a delação do Capitão Carlos: História e Historiografia de um personagem. Londrina: UEL, 2010. 1172-1185.

MENEZES, Nilson Monteiro. Ricardo Lunardelli: uma vida a serviço da terra. Curitiba: PR, 2015.

NOSSA, Leonêncio. Guerras desconhecidas do Brasil. Histórias de um país sem memória. Jornal O Estado de São Paulo. São Paulo, 19 de dezembro de 2010. Disponível em:< http://www.premiovladimirherzog.org.br/arquivo/254_2011_10_21_16_3_44.pdf> Acesso em 12 jan. 2017.

OIKAWA, Marcelo Eiji. Porecatu: a guerrilha que os comunistas esqueceram. São Paulo: Expressão Popular, 2011.

PEREIRA, Alceu. Reina Paz em Porecatu. Revista O Cruzeiro, de 25 de agosto de $\begin{array}{lllllll}1951 . & \text { p. } & 66 & - & 72 . & \text { Disponível } & \text { em: }<\end{array}$ http://memoria.bn.br/DocReader/docreader.aspx?bib=003581\&pasta=ano\%20195\&p esq=reina\%20a\%20paz\%20em\%20porecatu> Acesso em 11 jun 2017.

PIRES, João Ricardo Ferreira; BRAGAS, Pauliane de Carvalho; GERMANO, Ligia Beatriz de Paula. Revolta Camponesa de Porecatu. Portal do Professor. MEC: 22/11/2010. Disponível em:< http://portaldoprofessor.mec.gov.br/fichaTecnicaAula.html?aula=27034> Acesso em 12 nov. 2016 
PRIORI, Ângelo Aparecido. A Revolta Camponesa de Porecatu: A luta pela defesa da terra camponesa e a atuação do Partido Comunista Brasileiro (PCB) no campo (1942-1952). Dissertação de Mestrado, UNESP, Assis, 2000.

. Os comunistas vão ao campo: A Revolta Camponesa de Porecatu e a ção do PCB (1948-1952). ANPUH. Anais do XXII Simpósio Nacional de História: História, acontecimento e narrativa. João Pessoa: ANPUH, 2003. Disponível em:< http://anais.anpuh.org/?p=13919> Acesso em 14 jan. 2017.

A Revolta Camponesa de Porecatu. ANPUH. Anais do XXV Simpósio Nacional de História: História e Ética. Fortaleza: ANPUH, 2009. Disponível em:< https://anais.anpuh.org/?p=16454> Acesso em 14 jan. 2017.

O levante dos posseiros: A revolta camponesa de Porecatu e a ação do Partido Comunista Brasileiro no campo. Maringá: EDUEM, 2011.

ROSA FILHO, João Alves da. Porecatu, Sudoeste e outros episódios. Vol.III. Curitiba: Associação da Vila Militar, 2003.

SCHMIDT, Maria Auxiliadora; CAINELLI, Marlene. Ensinar História. São Paulo: Scipione, 2004.

SILVA, Joaquim Carvalho da. Terra Roxa de Sangue. Londrina: Ed. UEL, 1996.

SILVA, Osvaldo Heller da. A foice e a cruz. Comunistas e católicos na história do sindicalismo dos trabalhadores rurais do Paraná. Curitiba: Rosa de Bassi Gráfica e Editora. 2006.

A gênese do Sindicalismo Rural no paraná: Reflexões sobre as carreiras de dirigentes. IN: FERNANDES, Bernardo Mançano; MEDEIROS, Leonilde SErvolo de; PAULILO. Ignez (orgs). Lutas Camponesas contemporâneas: condições, dilemas e conquistas. São Paulo: Editora UNESP; Brasília. DF: Núcleo de Estudos Agrarios e Desenvolvimento Rural: 2009b. 


\section{APÊNDICE - REFERÊNCIAS DE NOTA DE RODAPÉ}

3. Osvaldo Heller da Silva explica que: "Bancando o aprendiz de feiticeiro, o PCB, até então confinado ao espaço urbano conseguiu penetrar nos sertões do Paraná [...] ensaiou a constituição de organizações rurais com características sindicais: as ligas camponesas do Paraná" (2006, p.51).

\section{Expressão utilizada por Osvaldo Heller da Silva (2006, p.54).}

5. Leonêncio Nossa (2010), escreve para o Jornal Estado de São Paulo que: "os comunistas foram chamados de traidores pelos líderes caboclos, por terem revelado táticas e números do movimento armado em sessões de tortura".

6. Homestead Act - Lei de Propriedade Rural criada por Abraham Linconl, em 1862, que teve por finalidade atrair imigrantes europeus para ocupar o solo americano e que definia a posse de 160 hectares de terra a quem a cultivasse por cinco anos, que acabou deflagrando a Marcha para o Oeste (ANTONELLI, 2013).

7. Para conversão deste valor ao padrão monetário atual Real $(R \$)$, fazer a divisão da quantia por 2.750.000.000.000.000.000, o que resultará no equivalente a 0,00000000000000000000036 reais. Fonte disponível em: <http://www.moedasdobrasil.com.br/moedas/reformas.asp> Acesso em 16 jun. 2017.

8. Lei 601, de 18 de setembro de 1850. Dispõe sobre as terras devolutas do Império. Disponível em: http://www.planalto.gov.br/ccivil_03/Leis/L0601-1850.htm>

9. Capitão Carlos era na verdade a alcunha de Celso Cabral de Mello. Ex-cabo radiotelegrafista da marinha, participante da insurreição militar de 1935. Com seu fracasso foi preso por seis meses, mas conseguiu fugir, em 1936. Em 1945 foi anistiado junto com Prestes e outros presos políticos da época, depois disso formouse na escola do PCB. E foi enviado pelo partido para ser comandante militar da luta armada em Porecatu, foi preso em junho de 1951 e acabou delatando os camaradas e passando à polícia informações sobre a localização dos acampamentos, 
armamentos, munições e quantidade de homens na resistência. Em 25 de agosto de 1951 fugiu da cadeia pública (OIKAWA, 2011, p.343-345).

Enviado: Junho, 2020.

Aprovado: Outubro, 2020. 